\title{
Dismantling the Beania magellanica (Busk, 1852) species complex (Bryozoa, Cheilostomata): two new species from European waters
}

\author{
Javier Souto $^{1,2}$ (D) $\cdot$ Karine B. Nascimento ${ }^{3} \cdot$ Oscar Reverter-Gil $^{4} \cdot$ Leandro M. Vieira $^{5}$ \\ Received: 4 May 2018 /Revised: 27 September 2018 / Accepted: 5 October 2018 / Published online: 6 November 2018 \\ (C) The Author(s) 2018
}

\begin{abstract}
New research on bryozoans has determined that formerly widespread species are in many cases complexes of similar, but distinct, species with more restricted distributions. Notwithstanding, the limits of distribution are still unresolved for many taxa, and occasionally a wide distribution is confirmed. Beania magellanica has been considered a widespread species, distributed throughout the Southern Hemisphere, parts of northern Pacific and Atlantic Oceans and the Mediterranean Sea. This study examines the Magellanic-type material, together with other historic samples and new specimens collected in the western Mediterranean and Adriatic, and for the first time, presents specimens from the European North Atlantic. Morphological comparisons and biometric analysis show the existence of three different species among the specimens studied. A redescription of B. magellanica based on the type specimen is presented, and two new species are described: $B$. serrata sp. nov. from the Northeast Atlantic and B. mediterranea sp. nov. from the Mediterranean Sea. These results indicate that B. magellanica s.l. is a large complex of species and that most specimens from different parts of the world must be revised.
\end{abstract}

Keywords North Atlantic $\cdot$ Mediterranean $\cdot$ Chile $\cdot$ Spain $\cdot$ Cryptogenic

\section{Introduction}

In the past, many bryozoan species were considered to be widely distributed or even cosmopolitan. Examples of such

This article is registered in ZooBank under urn:lsid:zoobank.org:pub: 7B9741A6-13ED-4FAE-BFE5-A4A92D68254B

Communicated by B. W. Hoeksema

Javier Souto

javier.souto-derungs@univie.ac.at

1 Institut für Paläontologie, Geozentrum, Universität Wien, Vienna, Austria

2 Facultade de Bioloxía, Departamento de Zooloxía, Xenética e Antropoloxía Fisica, Universidade de Santiago de Compostela, Santiago de Compostela, Spain

3 Centro de Biologia Marinha, Universidade de São Paulo, São Sebastião, SP, Brazil

4 Museo de Historia Natural da Universidade de Santiago de Compostela, Parque Vista Alegre s/n, 15705 Santiago de Compostela, Spain

5 Laboratório de Estudos de Bryozoa, Departamento de Zoologia, Centro de Biociências, Universidade Federal de Pernambuco, Recife, PE, Brazil species are abundant in literature from the nineteenth century and early twentieth century when, for instance, many European species were cited from different localities all around the world (e.g., Busk 1884; Harmer 1926, 1957). In some cases, these were simply misidentifications; but in many cases, cosmopolitan or widespread species reflect the failure to detect subtle diagnostic differences between very closely related species (Harmelin et al. 2012). In recent years, the use of modern techniques such as SEM, the redescription of the type material and to a lesser extent in bryozoans, gene sequencing has allowed splitting of putatively widespread species into complexes of similar but distinct species with more restricted geographical ranges (Berning and Kukliński 2008; Reverter-Gil et al. 2011; Vieira et al. 2013, 2014). These new findings seem more representative for the pattern of reproduction observed in bryozoans, which are colonial animals with a brooding reproductive mode that mostly produce non-feeding larvae with a short-lived pelagic phase and consequently with a limited range of larval dispersal (MacKinney and Jackson 1989).

Nevertheless, in some species, the issue of the wide distribution remains unresolved (Harmelin et al. 2012; Cumming and Tilbrook 2014). In some species, wide geographical distributions have been confirmed, for example, in several species of the genera Bugula Oken, 1815 (Fehlauer-Ale et al. 
2014; Ramalhosa et al. 2017), Bugulina Gray, 1848 (Ramalhosa et al. 2017), and Watersipora Neviani, 1896 (Vieira et al. 2014). Shallow-water bryozoans can be dispersed by rafting on natural floating substrates such as macroalgae, but also on artificial substrates of anthropogenic origin including drifting debris or the hulls of commercial or leisure vessels (e.g., Jackson 1986; Watts et al. 1998; Thiel and Gutow 2005; López-Gappa and Liuzzi 2018; Miranda et al. 2018). Even old records of widely distributed species apparently involve introduction by human activity centuries ago (Carlton 2009; Miranda et al. 2018).

Beania magellanica (Busk, 1852) is considered to be a widespread species, originally described by Busk (1852) from the Magellan Strait, Chile, where it was again recorded by Waters (1904) and Hastings (1943). Afterwards, it was recorded from the Atlantic Ocean in Cape Verde (Jullien 1888; Calvet 1907), Brazil (Hastings 1943), Argentina (Jullien 1888; Hastings 1943; López-Gappa 1989; Bastida et al. 1992; Moyano 2005; Liuzzi and López-Gappa 2011), Falkland Islands (Ortmann 1890; Hastings 1943; Moyano 2005), and Burdwood Bank (Hastings 1943). It was also recorded from the South African coasts (Jullien 1888; O'Donoghue and de Watteville 1944; O'Donoghue and Day 1957; Hayward 1980; Hayward and Cook 1983; Florence et al. 2007), the subantarctic region at Kerguelen (Busk 1879; Kluge 1914), Marion and Prince Edward Islands (Hastings 1943; Hayward 1995), the Pacific coast of Japan (Jullien 1888; Ortmann 1890; Yanagi and Okada 1918; Harmer 1926; Silén 1941), Mexico (Soule 1959), Peru (Osburn 1950, 1953) and Chile (Moyano 1999, 2009). In the Indo-Pacific region, B. magellanica was recorded from Australia (Hincks 1885; MacGillivray 1887; Harmer 1926; Vail and Wass 1981; Bock 1982; Winston 1986; Moran and Grant 1989, 1991, 1993; Connell 2001; Glasby et al. 2007; Piola and Johnston 2008), New Zealand (Busk 1852; Hutton 1891; Hamilton 1898; Waters 1906; Livingstone 1927; Gordon 1970, 1984, 1986; Bradstock and Gordon 1983; Rowden et al. 2004; Gordon et al. 2009), and New Caledonia (Gordon 2007). Finally, in the Mediterranean Sea, it has been extensively recorded from the western basin (Waters 1879, 1897; Jullien 1888; Gautier 1962; Prenant and Bobin 1966; Silén 1972; d'Hondt 1979; Zabala 1986; Saguar and Boronat 1987; Templado et al. 2002; Rosso et al. 2010), along with some records from the eastern basin, in Lebanon (Harmelin et al. 2016), and in Greece (Harmelin 1969; Hayward 1974; Gerovasileiou and Rosso, 2016), as well as in the Adriatic Sea (Heller 1867; Novosel and Požar-Domac 2001; Hayward and McKinney 2002; Novosel et al. 2004; Cocito et al. 2006; Cupido et al. 2007; Rosso et al. 2010) and African coast, mainly from Algeria and Tunisia (Gautier 1962; d'Hondt and Mascarell 2004; d'Hondt and Ben Ismail, 2008; Ayari-Kliti et al. 2012).

Here, we compare newly collected samples from off Atlantic northern Spain, the western Mediterranean Sea, and the northern Adriatic Sea with the type specimen of B. magellanica, material of historical collections and data from the literature. Two new species of Beania are described, establishing that $B$. magellanica actually represents a species complex.

\section{Material and methods}

Samples from two localities in the north Iberian Peninsula were collected. Surveys by scuba were done at Point Etxandarri, northern Spain, during summer 2016 and at the Ría of Ferrol, NW of Spain, during spring 2017. At Point Etxandarri, bryozoan colonies were scraped from vertical walls in microhabitats formed by the erect bryozoan Smittina cervicornis (Pallas, 1766). Parts of the samples were fixed in $96 \%$ alcohol and other samples were dried. At the Ría of Ferrol, algae were collected and the rocks scraped. Collected material was transported in seawater to the lab at the Marine Biological Station of the University of Santiago de Compostela on Ferrol, where samples were sorted under a binocular microscope and fixed in $70 \%$ alcohol.

In the Adriatic Sea, samples were also collected by scuba from two localities along the coast of the Istria Peninsula in early June 2017. We also studied samples from the Balearic Islands and the Mediterranean Iberian coast, collected during the sampling surveys Fauna Ibérica III and Fauna Ibérica IV, and stored in the Museo Nacional de Ciencias Naturales (MNCN), Madrid. One small sample collected in Banyulssur-Mer (Mediterranean coast, Southern France), assembled in a preparation for microscopy and stored in the Muséum National d'Histoire Naturelle (MNHN), Paris, was also studied. Finally, we also examined the type specimen of $B$. magellanica, other specimens collected from the Magellan Strait, Argentina, Falkland Islands, and Burdwood Bank, and specimens from Brazil and the Mediterranean Sea currently stored at the National History Museum (NHMUK), London.

Detailed data about the date of the sample collection, substrate, etc., when is known, are presented in the section of material examined for each species. Specimens were examined in the lab using a Leica MZ12 stereomicroscope, and optical photos were taken with a Zeiss SteREO Discovery V20 stereomicroscope. Selected specimens were dried for study by scanning electron microscopy (SEM). FEI Inspect S50 SEM and Zeiss EVO LS15, from the University of Vienna and from the University of Santiago de Compostela, respectively, were used to take photographs of uncoated material with back-scattered electron detector in low-vacuum mode. Specimens deposited at the NHMUK were photographed under a LEICA CRT5000 stereomicroscope and SEM images were made in a LEO 1455VP microscope. 
Colonies and zooids were measured using the software Image ${ }^{\circledR}$ on optical and SEM photographs. A total of 211 zooids were measured: 51 from the Balearic Islands, four from Banyuls-sur-Mer, 85 from northern Spain, 51 from the Adriatic, and 20 from Chile (ten on the type specimen, NHMUK 1854.11.15.100, and ten from the sample NHMUK 1958.4.14.6). It was not possible to include measurements of all examined specimens deposited at museum collections due different states of conservation and preservation of the colonies. Measurements of the total length and width of the autozooids, length and width of tube connections, and length and width of avicularia were taken. Total length versus width of each autozooid was represented graphically to compare the distribution of measurements in relation with its locality. Non-parametric multidimensional scaling (nMDS) was performed to test the null hypothesis that there are no significant morphometric differences between the zooids from the different geographic areas. Measurements of autozooid total length and width and of avicularia length and width were used in this analysis. Additional information about the morphology and distribution of B. magellanica was gathered from the literature.

New samples collected at Point Etxandarri, Ría of Ferrol, and the Adriatic Sea were sent to the Museo de Historia Natural, University of Santiago de Compostela (MHNUSC), Spain. Comparative specimens from Port-Cros Island (France), donated by Jean-Georges Harmelin and recorded in Harmelin (2017), were deposited in the Museu de Zoologia, University of São Paulo (MZUSP), Brazil.

\section{Results}

\section{Morphological and biometric analysis}

Analysis of the biometric and morphological data showed clear differences between the specimens from the Atlantic coast of northern Spain, the western Mediterranean and the Adriatic, and the type material of $B$. magellanica. Measurements of the samples from the different localities showed some differentiation between autozooid size (length and width) and avicularium size (length and width) (Table 1). The most striking feature was the separation of the samples into two clear groups based on autozooid size using the biometric analysis (nMDS and long vs. wide representation) (Fig. 1). A cluster with bigger zooids is formed by specimens from the Mediterranean studied here, whereas Atlantic specimens from northern Spain and the type material did not differ significantly, forming another cluster. Furthermore, in the western Mediterranean and Adriatic colonies, true spines were not observed and only two or four shallow folds in the oral area may be present. In contrast, in the other cluster, the autozooids exhibited four short oral spines: two distal and two distolateral ones. This morphological character, together with the significant difference in zooid size, justifies the distinction of the Mediterranean material as belonging to a new, different species.

In the second cluster, material from the Atlantic coast of northern Spain differed from the Magellan Strait material mainly in the morphology of the avicularium: the avicularium exhibits a serrated or denticulate distal rostrum in northern Atlantic Spain but a straight rostrum in the Magellan Strait (as is also the case in the material from the Mediterranean) (Fig. 2). Moreover, in Spanish specimens, the two distal spines are reduced or lacking in zooids with an ooecium. These differences in the Spanish Atlantic material justify the description of a new, distinct species.

\section{Systematics}

Class Gymnolaemata Allman, 1856

Order Cheilostomata Busk, 1852

Family Beaniidae Canu and Bassler, 1927

Genus Beania Johnston, 1840

Beania magellanica (Busk, 1852)

(Figs. 2a and 3; Table 1)

Diachoris magellanica Busk, 1852: 54, pl. 67; Busk 1884: 59

Beania magellanica: Waters 1904: 28, pl. 08, fig. 7 a-c; Hastings 1943: 414

\section{Material examined}

Holotype: Diachoris magellanica, NHMUK 1854.11.15.100, Magellan Strait, Chile, G. Busk Collection, collector Charles Darwin, 10-20-m depth.

Other material: Brazil-NHMUK 1899.7.1.4674, John Adams Bank, off Espírito Santo, G. Busk Collection. Argentina-NHMUK 1934.11.12.23, 51 ${ }^{\circ} 35^{\prime} \mathrm{S}, 65^{\circ} 39^{\prime} \mathrm{W}$, St. 314, G. Busk Collection, H.M.S. Challenger, 70-m depth;


Discovery Investigations, 164-170-m depth, 05/xii/1931;

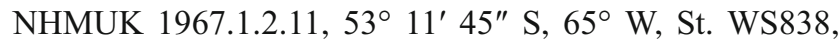
Discovery Investigations, 148-159-m depth, 05/ii/1932; NHMUK 1996.12.4.24/25/26, $46^{\circ} \mathrm{S}, 60^{\circ} 05^{\prime} \mathrm{W}$, St. WS237, Discovery Investigations, 150-246-m depth, 07/vii/1928; NHMUK 1996.12.22.4, 50 $35^{\prime} \mathrm{S}, 57^{\circ} 20^{\prime} \mathrm{W}$, St. WS229, Discovery Investigations, 210-271-m depth, 01/vii/1928. Chile-NHMUK 1958.4.14.6, 1996.12.11.2, Magellan Strait, St. 1321, Discovery Investigations, 66-m depth, 16/iii/ 1934. Falkland Islands-NHMUK 1887.12.9.298/300, 1944.1.8.154, Port Jackson, $51^{\circ} 40^{\prime} \mathrm{S}, 57^{\circ} 50^{\prime} \mathrm{W}$, St. 315, G. Busk Collection, H. M. S. Challenger, 5-12-m depth; NHMUK 1947.4.22.207, Port Stanley, St. 58, Discovery Investigations, 1-2-m depth, 19/v/26; NHMUK 1996.12.4.14/15/18/20, off Lion Island, St. WS84, 
Table 1 Biometrics of specimens of Beania magellanica Busk, 1852, Beania serrata sp. nov. and Beania mediterranea sp. nov. from different localities

\begin{tabular}{|c|c|c|c|c|c|c|}
\hline & & Mean & SD & Minimum & Maximum & $N$ \\
\hline \multirow{12}{*}{$\begin{array}{l}\text { Beania } \\
\quad \text { magellanica }\end{array}$} & Holotype & & & & & \\
\hline & Autozooid length & 0.707 & 0.0263 & 0.675 & 0.747 & 10 \\
\hline & Autozooid width & 0.313 & 0.0227 & 0.277 & 0.351 & 10 \\
\hline & Tubular connection length & 0.101 & 0.0139 & 0.074 & 0.131 & 18 \\
\hline & Tubular connection width & 0.054 & 0.0076 & 0.045 & 0.075 & 18 \\
\hline & Avicularium length & 0.251 & 0.0235 & 0.225 & 0.288 & 9 \\
\hline & Avicularium width & 0.097 & 0.0112 & 0.071 & 0.109 & 9 \\
\hline & NHMUK1958.4.14.6 Chile & & & & & \\
\hline & Autozooid length & 0.686 & 0.0313 & 0.635 & 0.738 & 10 \\
\hline & Autozooid width & 0.313 & 0.0215 & 0.282 & 0.344 & 10 \\
\hline & Avicularium length & 0.326 & 0.0138 & 0.303 & 0.355 & 10 \\
\hline & Avicularium width & 0.115 & 0.0117 & 0.099 & 0.131 & 10 \\
\hline \multirow{14}{*}{$\begin{array}{l}\text { Beania } \\
\quad \text { serrata } n . \mathrm{sp} .\end{array}$} & NW Spain, Ferrol & & & & & \\
\hline & Autozooid length & 0.679 & 0.0401 & 0.597 & 0.745 & 60 \\
\hline & Autozooid width & 0.355 & 0.0187 & 0.326 & 0.422 & 60 \\
\hline & Tubular connection length & 0.165 & 0.0244 & 0.114 & 0.228 & 38 \\
\hline & Tubular connection width & 0.068 & 0.0104 & 0.051 & 0.097 & 38 \\
\hline & Avicularium length & 0.276 & 0.0223 & 0.232 & 0.337 & 26 \\
\hline & Avicularium width & 0.106 & 0.0103 & 0.085 & 0.132 & 26 \\
\hline & N Spain, Point Etxandarri & & & & & \\
\hline & Autozooid length & 0.666 & 0.0524 & 0.578 & 0.757 & 25 \\
\hline & Autozooid width & 0.291 & 0.0322 & 0.236 & 0.365 & 25 \\
\hline & Tubular connection length & 0.101 & 0.0232 & 0.064 & 0.144 & 19 \\
\hline & Tubular connection width & 0.041 & 0.0078 & 0.030 & 0.056 & 19 \\
\hline & Avicularium length & 0.243 & 0.0302 & 0.195 & 0.291 & 25 \\
\hline & Avicularium width & 0.086 & 0.0131 & 0.061 & 0.106 & 25 \\
\hline \multirow{17}{*}{$\begin{array}{l}\text { Beania mediterranea } \\
\quad n . \mathrm{sp} .\end{array}$} & Balearic Island & & & & & \\
\hline & Autozooid length & 0.853 & 0.0439 & 0.775 & 0.957 & 51 \\
\hline & Autozooid width & 0.456 & 0.0282 & 0.406 & 0.529 & 51 \\
\hline & Tubular connection length & 0.231 & 0.0402 & 0.180 & 0.340 & 22 \\
\hline & Tubular connection width & 0.071 & 0.0121 & 0.050 & 0.100 & 22 \\
\hline & Avicularium length & 0.367 & 0.0269 & 0.320 & 0.418 & 44 \\
\hline & Avicularium width & 0.136 & 0.0131 & 0.117 & 0.173 & 44 \\
\hline & Banyuls & & & & & \\
\hline & Autozooid length & 0.953 & 0.0330 & 0.910 & 0.990 & 4 \\
\hline & Autozooid width & 0.428 & 0.0096 & 0.420 & 0.440 & 4 \\
\hline & Adriatic Sea & & & & & \\
\hline & Autozooid length & 0.877 & 0.0556 & 0.742 & 0.991 & 51 \\
\hline & Autozooid width & 0.470 & 0.0510 & 0.342 & 0.568 & 51 \\
\hline & Tubular connection length & 0.222 & 0.0350 & 0.139 & 0.295 & 38 \\
\hline & Tubular connection width & 0.082 & 0.0180 & 0.059 & 0.139 & 38 \\
\hline & Avicularium length & 0.336 & 0.0474 & 0.250 & 0.402 & 41 \\
\hline & Avicularium width & 0.121 & 0.0198 & 0.078 & 0.168 & 41 \\
\hline
\end{tabular}

$S D$, standard deviation; $N$, number of measurements
Discovery Investigations, 74-75-m depth, 24/iii/1927; NHMUK 1996.12.4.16/17/21/22/23, off Lively Island, St. WS85, Discovery Investigations, 79-m depth, 25/iii/1927; NHMUK 1930.1.16.13, Roy Cove; NHMUK 1935.3.6.327/
401, Whaler Bay, Vallentin Collection; NHMUK 1935.3.6.328, Stanley Harbour, Vallentin Collection. Burdwood Bank-NHMUK 1996.10.11.1, St. 1909, Discovery Investigations, 132-m depth, 30/iv/1936. 


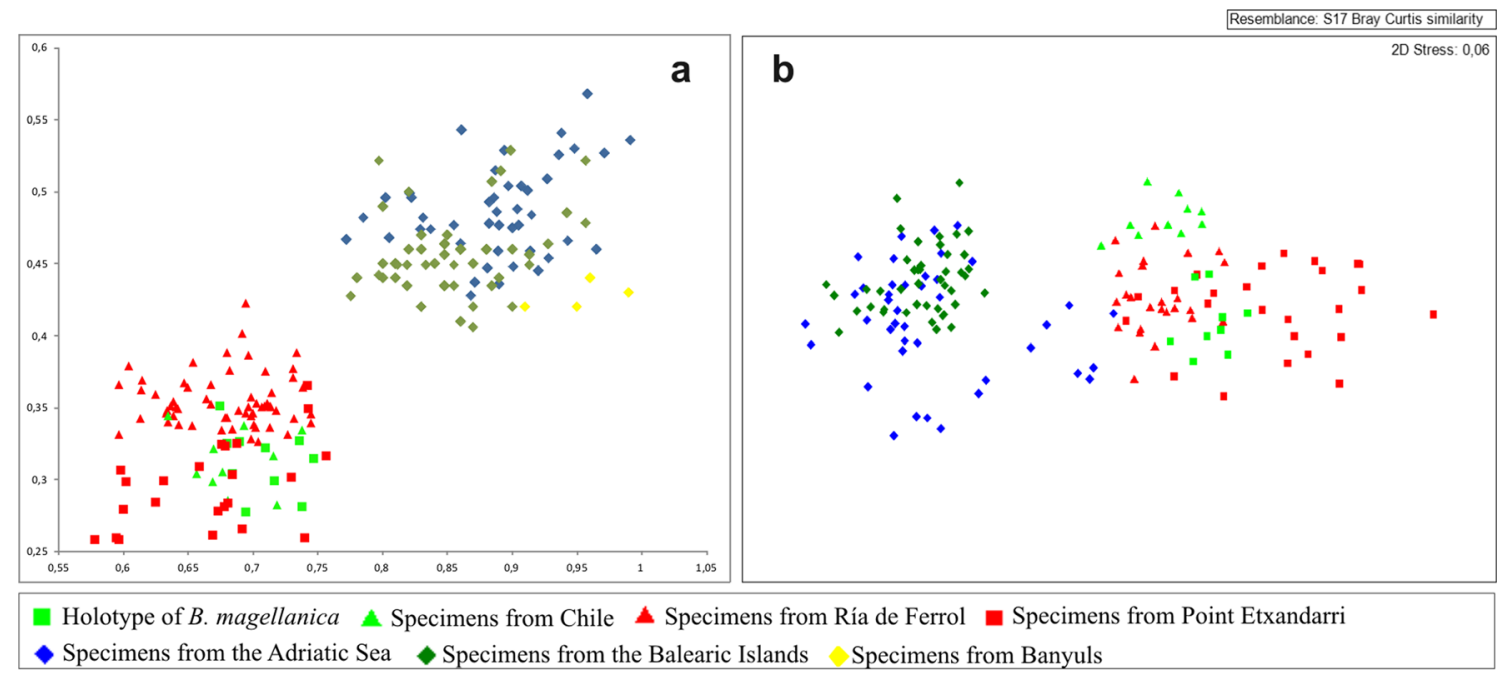

Fig. 1 Biometric analysis of zooids by localities. a Graphical representation of zooidal length vs. zooidal width. b nMDS analysis of zooidal biometrics

\section{Description}

Colony creeping, reticulated, forming a sheet with network aspect and supported above the substrate, and fixed to it, by smooth tubular rootlets resembling holdfast tips. Autozooids disjunct, elongate oval, boat-shaped, linked by tubular elongations of the lateral and abfrontal wall, each zooid with six tubes, one distal (in the opposite region of the opening of the operculum), two distolateral, two proximolateral, and one in the most proximal portion of the zooid, each connection with a septum. Frontal wall completely membranous, without frontal or marginal spines. Four (rarely two or none) small oral spines, two on distal corners facing up, and two distolateral. Distal end of the autozooid lightly rounded or straight, with the edge of the operculum fitting to the distal rim. One or two monomorphic avicularia, pedunculate, with bird's head form, about half of zooidal length, attached by a short tube near each distolateral tubular connection, elongate cystid, almost funnelshaped, with dorsal wall rounded in profile, occupying about three fifths of avicularium length, rostrum (not visible in type material) downcurved distally, smooth, tapering distally, mandible with single, hooked tip. Ooecium vestigial (not visible in type material), resembling a small cap at the distal zooidal edge, zooid with ooecium with more spaced distal spines.

\section{Remarks}

Busk's type is a small colony preserved on a balsam slide, making it difficult to characterize certain morphological features of this species, including avicularia and ooecia. Therefore, the above description includes data from the type specimen as well as additional material from the Magellan Strait.

\section{Beania serrata sp. nov.}

(Figs. 2b, 4, and 5; Table 1)

urn:lsid:zoobank.org:act:D17A2B14-77AF-4349-B9F3321D37D7F39E

\section{Material examined}

Holotype: MHNUSC 10087, Pta. Piteira, Ría de Ferrol, Spain, NE Atlantic, $43^{\circ} 27^{\prime} 52^{\prime \prime} \mathrm{N}, 08^{\circ} 15^{\prime} 43^{\prime \prime} \mathrm{W}, 5-16-\mathrm{m}$ depth, 25/ 05/2017 on Gloiocladia repens (C. Agardh) Sánchez and Rodríguez-Prieto in Rodríguez-Prieto et al. (2007).

Paratypes: MHNUSC 10088, 10089, 10090, same locality of the Holotype, MHNUSC 10106, Point Etxandarri, Spain, NE Atlantic $43^{\circ} 26^{\prime} 32.1^{\prime \prime} \mathrm{N}, 2^{\circ} 55^{\prime} 27.5^{\prime \prime} \mathrm{W}, 25-\mathrm{m}$ depth, 04/ 08/2016, on S. cervicornis (Pallas, 1766).


Fig. 2 Comparison of avicularia. a Avicularium of B. magellanica Busk, 1852 (NHMUK 1996.12.11.2, Chile). b Avicularium of B. serrata sp. nov. (MHNUSC 10087, Ría de Ferrol, Spain). c Avicularium of B. mediterranea sp. nov. (MHNUSC 10104, Croatia) 
Fig. 3 Beania magellanica Busk, 1852. a-c Holotype specimen from the Magellan Strait (NHMUK 1854.11.15.100): a general aspect of colony, $\mathbf{b}$ detail of distal portion of one zooid with two avicularia, and $\mathbf{c}$ avicularium. d Portion of one colony with avicularia in all zooids (NHMUK 1958.4.14.6, Chile). e SEM image of zooid (NHMUK 1996.12.11.2, Chile)
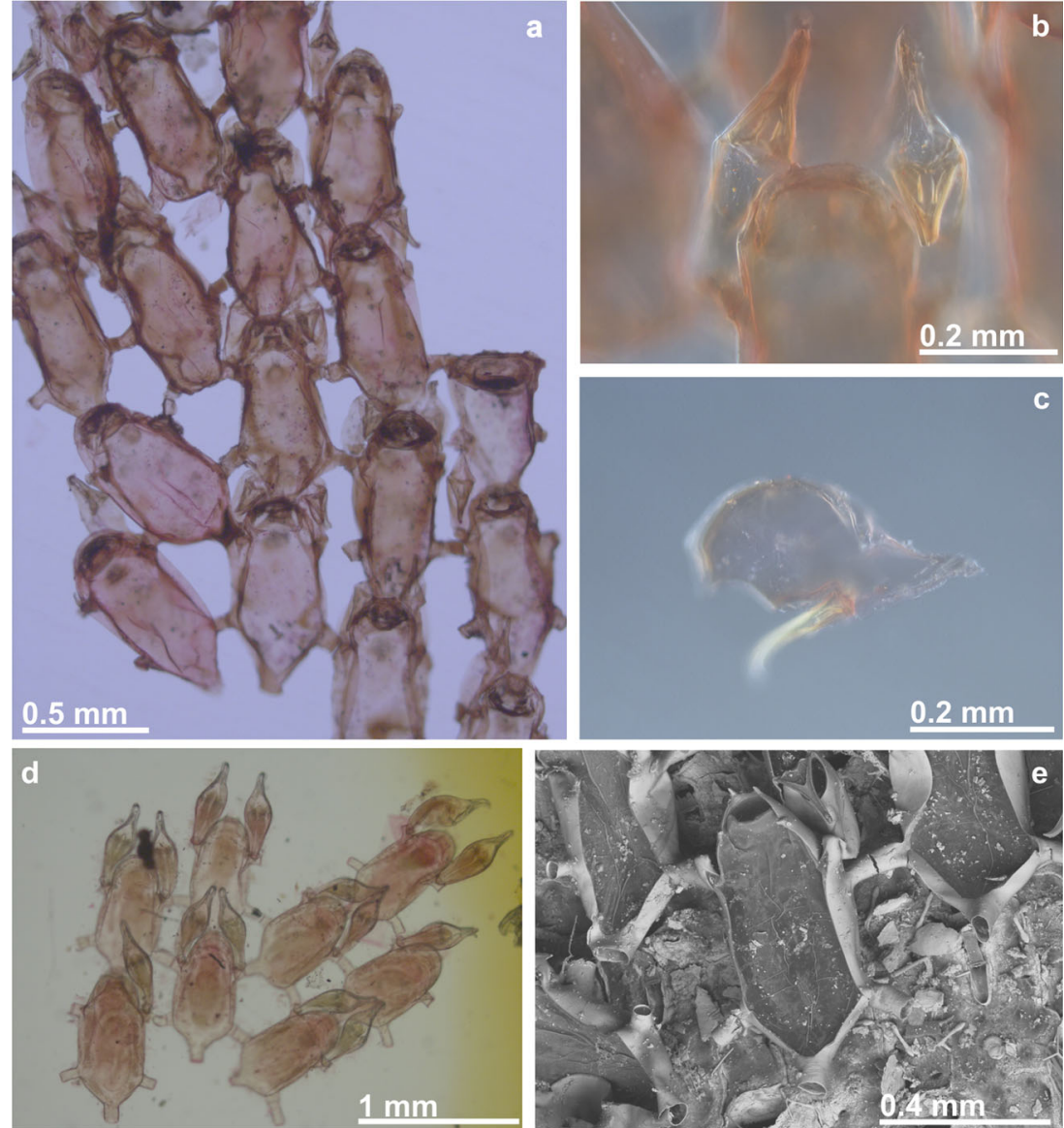

Etymology: serrata, alluding to the serrate aspect of the avicularian rostrum, one of the main differences between this and the other two species described herein.

\section{Description}

Colonies forming a sheet with network aspect, supported above the substrate, and fixed to it, by rootlets of different size, from short to more than $1 \mathrm{~mm}$ long, rootlets growing from the distal basal part of the zooid, below the distal tubular intrazooidal connection, with terminal end resembling a holdfast tip. Autozooids disjunct, elongate oval, boat-shaped, linked by tubular connections, each autozooid with six tubes, one distal, two distolateral, two proximolateral, and one proximal. A septum, visible by transparency, in the middle of the tubular connections, with numerous small rounded pores forming a circle. Frontal wall completely membranous. Four small spines present, two distal and two lateral to the orifice, with the two distal ones very reduced or absent in zooids with ooecium. Distal end of autozooid lightly rounded or straight, with the edge of the operculum fitting to the distal rim. One or two monomorphic avicularia, pedunculate, with bird's head form and very mobile, about half zooidal length, attached by a short tube near each distolateral tubular connection and directed frontally, elongate cystid, almost funnel-shaped, with dorsal wall rounded in profile, rostrum downcurved distally, showing a denticulate border, with serrated aspect. Ooecium very reduced, like a small cap in the distal margin with two lateral uncalcified lines.

\section{Remarks}

Beania serrata sp. nov. differs from B. magellanica mainly in the rostrum of avicularia having a denticulate border. Specimens of $B$. serrata sp. nov. were collected in the Atlantic, north and north-west of Spain. The bryozoan fauna of these areas was well studied in the past, but there are no previous records of $B$. magellanica here. Moreover, both areas are under high anthropogenic pressure, with large harbor areas and dense maritime traffic. Therefore, this species is considered cryptogenic until more studies can be conducted on it and related species.

\section{Beania mediterranea sp. nov.}

(Figs. 2c and 6; Table 1)

urn:Isid:zoobank.org:act:8D4CCBF4-E4BC-4EFF-A94DA48723C74444

Diachoris buskiana Hutton, 1873: Waters 1879: 120, pl. 12, fig. 1 
Fig. 4 Beania serrata sp. nov. from Ría de Ferrol, Spain (NE Atlantic). a, b Optical frontal view of colony (MHNUSC 10087, Holotype). c Optical photo of basal wall, arrows show rhizoids (MHNUSC 10087, Holotype). d SEM image of colony (MHNUSC 10088, Paratype). e, f Zooids with distal avicularia and distal spines (MHNUSC 10088, Paratype). g Zooid with ooecium, arrows show proximal-most spines (MHNUSC 10088, Paratype). h Optical photo of distal part of one zooid with ooecium, arrows show reduced distal spines
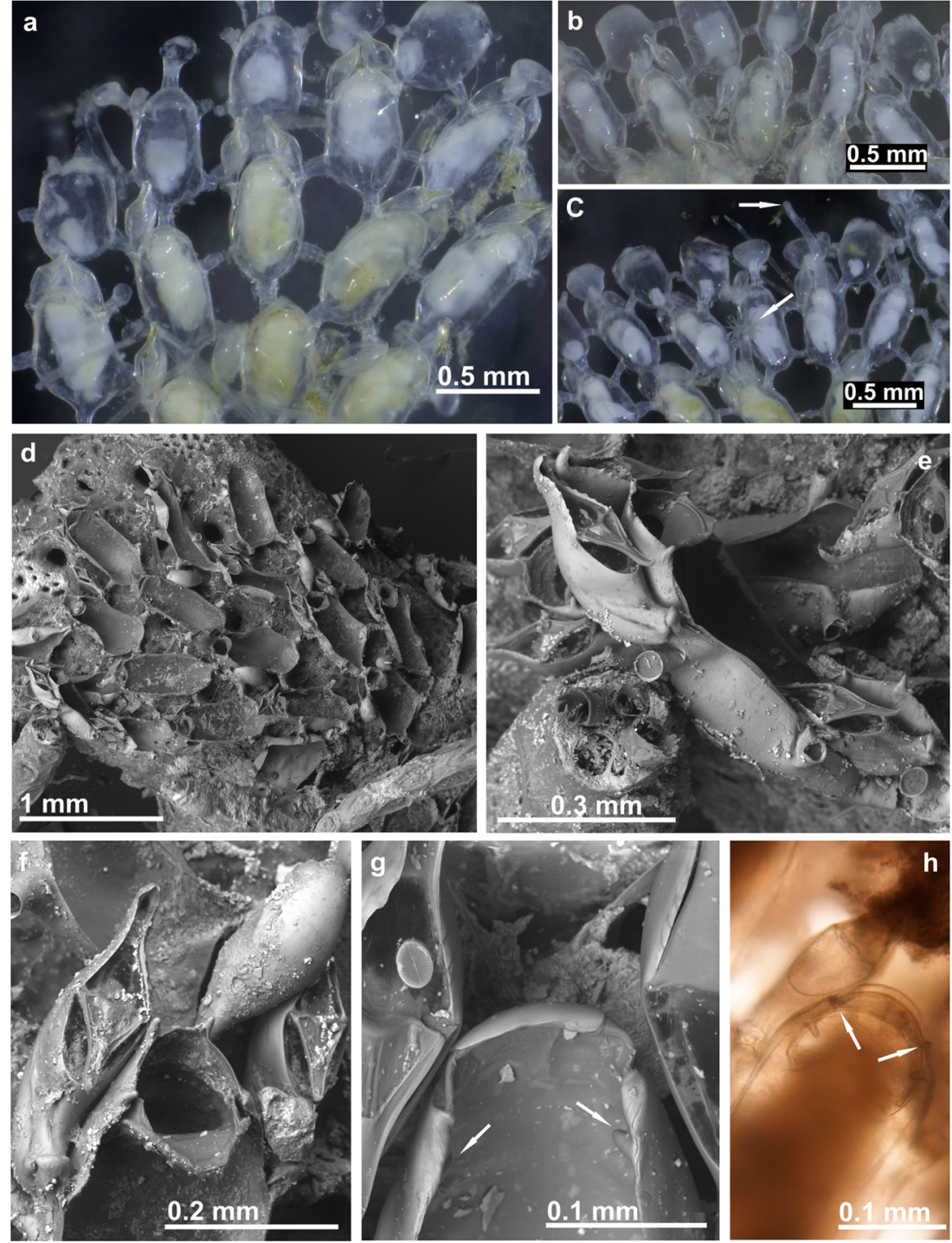

Beania magellanica: Waters 1897: 16, pl. 2, figs. 11-14 (?); Harmer 1926: 412, pl. 28, figs. 1-4 (?); Calvet 1927: 4 (?); Gautier 1962: 97; Prenant and Bobin 1966: 555, fig. 191; Zabala 1986: 333, fig. 96; Zabala and Maluquer 1988: 101, fig. 176; Hayward and McKinney 2002: 24, fig. $10 \mathrm{~A}-\mathrm{B}$
Fig. 5 Beania serrata sp. nov. (MHNUSC 10087, Holotype, Ría de Ferrol, Spain). a Septum in a tubular connection between zooids. b SEM image showing avicularia and distal spines. c Avicularium aspect
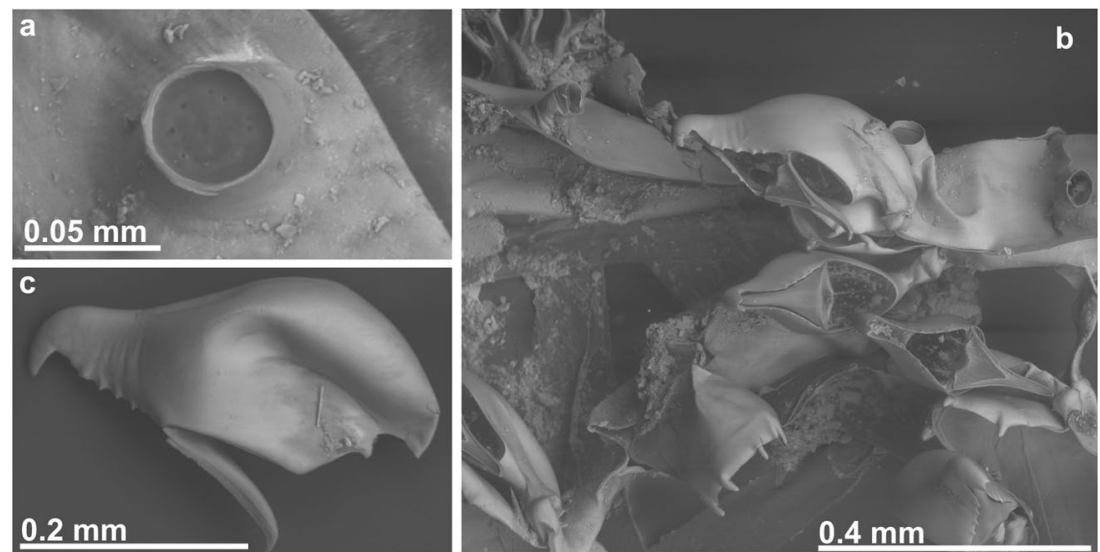
Fig. 6 Beania mediterranea sp. nov. a Aspect of colony with tentacle crown expanded. b Optical photos of zooids with avicularia (MHNUSC 10105, Paratype, Croatia). c, d Zooids and avicularia in an SEM image (MHNUSC 10105, Paratype, Croatia). e Septum in a tubular connection between zooids (MHNUSC 10104, Holotype, Croatia). $\mathbf{f}-\mathbf{h}$ Avicularia (MHNUSC 10104, Holotype, Croatia)
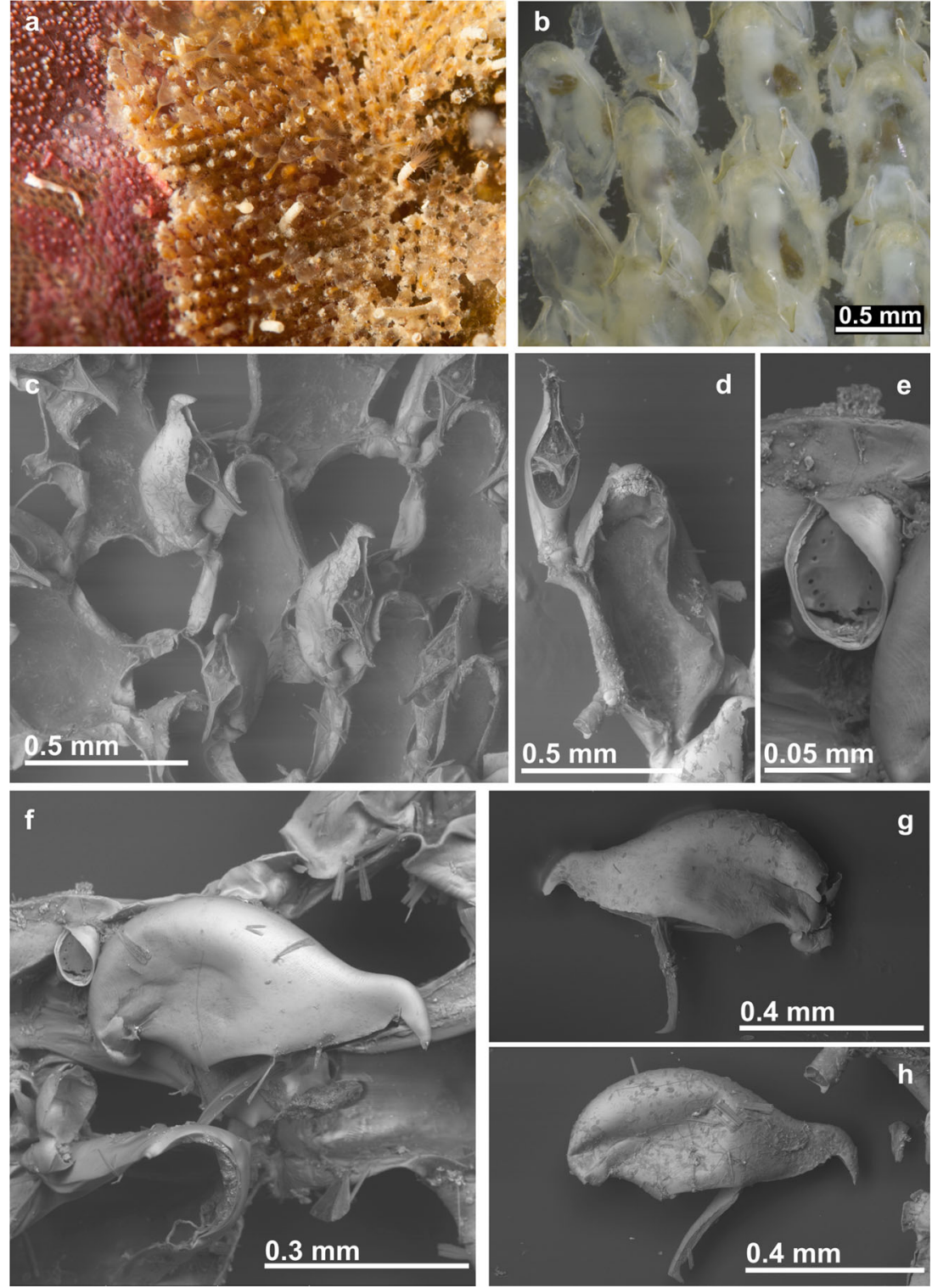

\section{Material examined}

Holotype: MHNUSC 10104, Brijuni Island, Croatia, Adriatic Sea, 44 $54^{\prime} 04^{\prime \prime}$ N, $13^{\circ} 46^{\prime} 07^{\prime \prime}$ E, 20-m depth, 03/06/2017, on calcified red seaweeds.

Paratypes: MHNUSC 10105, Zlatne Stijene, Pula, Croatia, Adriatic Sea, $45^{\circ} 50^{\prime} 11^{\prime \prime} \mathrm{N}, 13^{\circ} 49^{\prime} 35^{\prime \prime}$ E, 24-m depth, 03/06/ 2017, on calcified red seaweeds.

Other material: Balearic Islands (Mediterranean)MNCN 25.03/557, 25.03/736, I. Conejera, Ibiza, Loc. 259B, FAUNA III, 35 m; MNCN 25.03/1132, I. Tagomaro, Ibiza, Loc. 236B4, FAUNA III, 17.3-m depth; MNCN 25.03/1658, Isla Bleda Mayor, Ibiza, Loc. 258B3, FAUNA III, 6-45-m depth; MNCN 25.03/675, Pta. Jova, Mallorca, Loc. 179 B1, FAUNA III, 13.3-m depth; MNCN 25.03/712, I. de Toro, Mallorca, Loc. 230B14, FAUNA III, 30-m depth; MNCN
25.03/1072, Pta. de La Guardia, Mallorca, Loc. 222 A, FAUNA III, 92-97-m depth; MNCN 25.03/1095, Isla de Dragonera, Mallorca, Loc. 177B2, FAUNA III, 31.3-m depth. Iberian Peninsula (Mediterranean)-MNCN 25.03/3107, Islas Columbretes, Castellón, Loc. 293A, FAUNA IV, 7881-m depth; MNCN 25.03/3158, Islas Columbretes, Castellón, Loc. 283A, FAUNA IV, 80-85-m depth. France (Mediterranean)-MNHN 1173, Banyuls-sur-Mer, 06/vi/ 1962; NHMUK 1975.4.20.5, Cassis, Marseille, JeanGeorges Harmelin Collection, 30-m depth, 27/viii/1974; MZUSP 1312, Montremian, Port-Cros Island, collector Jean-Georges Harmelin, 27-m depth, 05/v/2016. Italy (Ligurian Sea)-NHMUK 1968.1.16.2, Santa Margherita, Riviera Levante; (Tyrrhenian Sea) NHMUK 1879.4.25.45, Naples, Waters Collection. Adriatic Sea-NHMUK 1911.10.1.304; NHMUK 1912.12.21.923, Norman 
Collection. Greece (Aegean Sea)-NHMUK 1975.1.12.118/ 123/124/128/130, Cape Mastika, Chios, Expedition to Chios, University College Swansea, viii/1967; NHMUK 1975.1.12.122/125/129, Venetica, Chios, Expedition to Chios, University College Swansea, viii/1967; NHMUK 1975.1.12.122, Dhiaporia, Chios, Expedition to Chios, University College Swansea, viii/1967.

Etymology: Alluding to the presence of this species in Mediterranean waters.

\section{Description}

Colonies encrusting, forming a sheet with network aspect, supported above the substrate, and fixed to it, by rootlets with holdfast tip. Autozooids disjunct, each zooid with six tubular connections, one distal, two distolateral, two proximolateral, and one proximal, a septum, visible by transparency, in the middle of the tubular connections, with numerous small rounded pores forming a circle. Autozooids large, elongate oval, boat-shaped, with frontal wall completely membranous. No true oral spines present, two or four small distal projections occasionally present, which may move to the distal corners in the presence of an ooecium. Distal border of autozooids rounded, with edge of operculum fitting to the distal rim. One or two monomorphic avicularia, pedunculate, with bird's head form and very mobile, attached by a short tube near each distolateral tubular connection and directed frontally, elongate cystid, almost funnel-shaped, with dorsal wall rounded in profile, rostrum downcurved distally, hooked, without denticulate border. Ooecium very reduced, detected only by the presence of a small distal cap with small uncalcified distolateral areas. 24-28 tentacles.

\section{Remarks}

Samples here ascribed to B. mediterranea sp. nov. come from different Mediterranean areas: the Balearic Islands, Spanish Levante (Castellón), Southern France (Banyuls-sur-Mer, Marseille, and Port-Cros Island), Southern Italy (Naples), the Northern Adriatic and the Eastern Mediterranean (Chios). All this material differs from B. magellanica and B. serrata sp. nov. in the absence of oral spines as well as bigger zooids and avicularia, which lack a denticulate rostrum. Specimens assigned to B. magellanica by Hayward and McKinney (2002) from the Adriatic and by Prenant and Bobin (1966) and Zabala (1986) from the western Mediterranean definitely correspond to B. mediterranea sp. nov. Prenant and Bobin (1966) and Zabala (1986) indicated the presence of distal spines in the autozooids, though vestigial. The figure by Prenant and Bobin (1966, fig. 191) actually shows only two distal shallow folds, while the key by Zabala and Maluquer (1988) indicates that B. magellanica lacks spines or that they are vestigial. On the other hand, Waters (1879) reported that
"Just above the aperture are from two to four small projections on the zooecium" in material from Naples, but he did not refer to real spines. The revision of Waters' original specimens in the NHMUK proves the lack of true spines in this material, which is also referred here to $B$. mediterranea sp. nov.

The identity of other nominal records of B. magellanica from the Mediterranean could not be confirmed and should be revised, including those from the Adriatic (Heller 1867; Novosel et al. 2004; Cocito et al. 2006), Italy (Waters 1897; Harmer 1926; Rosso et al. 2010; Rosso and Di Martino 2016), Balearic Islands (Calvet 1927; Zabala 1993); Banyuls-surMer (Calvet 1927), Islas Columbretes (d'Hondt 1979; Saguar and Boronat 1987), Lebanon (Harmelin et al. 2016), and Greece (Gerovasileiou and Rosso 2016). Nonetheless, most of those records likely correspond to B. mediterranea sp. nov.

\section{Discussion}

Besides the variability described in our material and included in the above results, certain other variations in the material examined as well as in the descriptions from the literature were observed, although these probably lack taxonomic meaning. For instance, one or two avicularia may be present in different zooids in our material (as also described or figured in the literature (e.g., Prenant and Bobin 1966; Hayward and McKinney 2002)), but a real pattern was not observed. Also, the length of the tubular connections between autozooids is very variable, with proportionally the highest standard deviation of all the measurements taken (Table 1). This variation probably depends on the substrate because colony morphology varies according to substrate heterogeneity. In the western Mediterranean localities studied here, all specimens were found on calcareous algae, but in the Adriatic, specimens were found on bryozoans (Schizoretepora serratimargo (Hincks, 1886)) as well as on calcareous algae. In the NW Mediterreanean, B. magellanica s.l. is particularly common in coralligenous grounds where it is epibiont of many taxa, such as coralline algae and sponges (Harmelin 2017). In northern Spain, colonies of B. serrata sp. nov. grew on the alga $G$. repens and on the bryozoan $S$. cervicornis (no substrate data are available for specimens deposited at the NHMUK). This variability in the length of the tubular connections was also observed in other bryozoan species, such as genus Mollia Lamouroux, 1816 (Berning 2006; Lamouroux 1816; Souto et al. 2010a), with a similar colonial development, i.e., fixed to the substrate by rootlets that avoid contact of the basal wall with the substrate and settlement on similar substrates, mainly coralline algae.

As noted in the introduction, B. magellanica has so far been considered a widespread species, reported from all around the world (Fig. 7). Nonetheless, all these records should be revised according to the new data presented here. The observed 


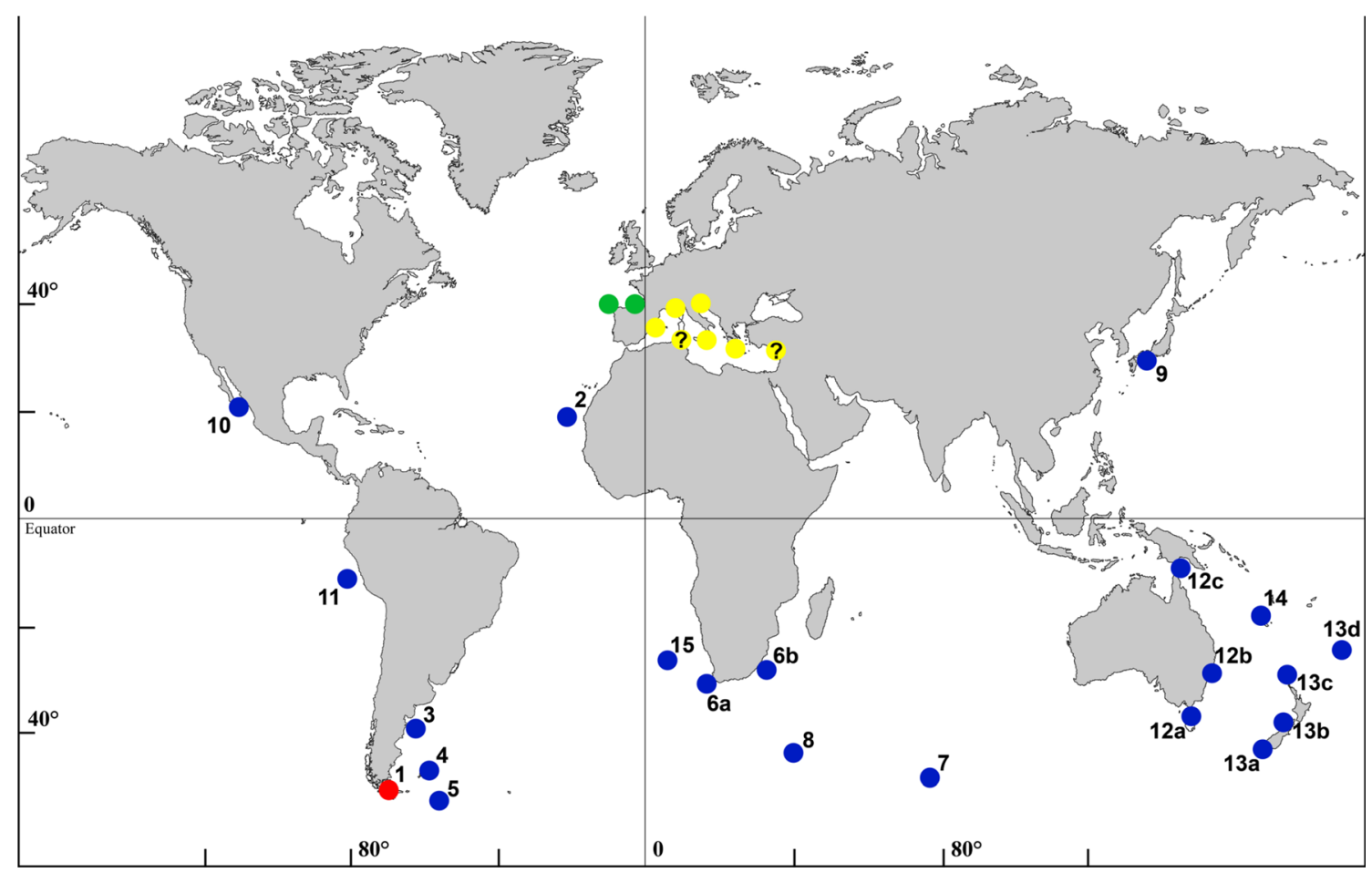

Fig. 7 Distribution of Beania magellanica s.l. Red circle, type locality of $B$. magellanica; blue circles, summary of localities with $B$. magellanica s.l. records in areas not studied in the present paper; green circles, localities of $B$. serrata sp. nov.; yellow circles, localities of $B$. mediterranea sp. nov., with question mark (?), localities with record as $B$. magellanica, and that could probably be B. mediterranea, but whose identity should be checked. References from areas or samples not included in the present paper: (1) Magellan Strait, Chile (Busk 1852; Waters 1904; Hastings 1943; Moyano 1999, 2009); (2) Cape Verde (Jullien 1888; Calvet 1907); (3) Argentina (Jullien 1888; Hastings 1943; Moyano 2005; López-Gappa 1989; Bastida et al. 1992, Liuzzi and López-Gappa 2011); (4) Falkland Islands (Ortmann 1890; Hastings 1943; Moyano 2005); (5) Burdwood Bank (Hastings 1943); (6) South African coasts, a (Jullien 1888; O'Donoghue and de Watteville 1944;
O'Donoghue and Day 1957; Florence et al. 2007) and b (Hayward 1980; Hayward and Cook 1983); (7) Kerguelen (Busk 1879; Kluge 1914); (8) Marion and Prince Edward Islands (Hastings 1943; Hayward 1995); (9) Pacific coast of Japan (Jullien 1888; Ortmann 1890; Yanagi and Okada 1918; Harmer 1926; Silén 1941); (10) Mexico (Soule 1959); (11) Peru (Osburn 1950, 1953); (12) a-c, Australia (Hincks 1885; MacGillivray 1887; Harmer 1926; Vail and Wass 1981; Bock 1982; Winston 1986; Moran and Grant 1989, 1991, 1993; Connell 2001; Glasby et al. 2007; Piola and Johnston 2008); (13) a-d, New Zealand (Busk 1852; Hutton 1891; Hamilton 1898; Waters 1906; Livingstone 1927; Gordon 1970, 1984, 1986; Bradstock and Gordon 1983; Rowden et al. 2004; Gordon et al. 2009); (14) New Caledonia (Gordon 2007); (15) Vema seamount, JS, unpublished data

habitats have been considered native in the type localities, as in the case of some pseudo-indigenous species (Carlton 2009; Rocha et al. 2013; Marchini et al. 2015; Miranda et al. 2018). At the same time, the lack of data from the sampled area may have led to the misassignment of the exotic status in various marine species (Zenetos et al. 2017), including bryozoans (Rocha et al. 2013; Miranda et al. 2018).

Thus, the absence of previous records of B. magellanica s.l. from the European Atlantic coast suggests that $B$. serrata sp. nov. was recently introduced here by anthropogenic activities. The Ría de Ferrol is home to major shipyards and a naval industry, and Point Etxandarri is close to the harbor of Bilbao. This causes both areas to have high anthropogenic pressure through commercial and leisure vessel traffic. The fauna of both areas is well-known, in particular that of the Ría de Ferrol, which has been systematically, at least yearly, surveyed since about 25 years ago. Until now, B. magellanica s.l. was never recorded there, so most probably the species 
was introduced during recent years. This is not the first time that a new bryozoan immigrant has been detected in that area. During the 1990s, a widespread species, Watersipora subatra (Ortmann, 1890), was detected for the first time in the nearby coast of Lugo (César-Aldariz et al. 1997 as W. subovoidea), and only a few years ago, it began to spread along the whole north Iberian coast (JS, unpublished data). Also, during the 1990s, Tricellaria inopinata d'Hondt and Occhipinti Ambrogi, 1985 was first detected at the coast of Lugo, and it has now colonized the whole Galician coast as well as the Bay of Biscay (De Blauwe and Faasse 2001; Fernández-Pulpeiro et al. 2002; Cook et al. 2013). Another well-known invasive species, Amathia verticillata (Delle Chiaje, 1822), was detected in Galicia and Santander for the first time a few years ago (Souto et al. 2010b; Reverter-Gil et al. 2016). Finally, several well-known invasive species of the genera Bugula and Bugulina are present along the whole north Iberian coast (JS and ORG, unpublished data).

\section{Conclusions}

Although B. magellanica is considered a widespread species, which has probably been transported by human activities, there are some misidentified specimens around the world and it apparently represents a large species complex of closely related species. Here, we describe two new species closely resembling $B$. magellanica: $B$. serrata $\mathrm{sp}$. nov. from the Atlantic coast of northern Spain, and B. mediterranea sp. nov. from the Mediterranean coast. The latter species was previously identified as $B$. magellanica, whereas the $B$. serrata $\mathrm{sp}$. nov. was probably recently introduced into the area. The presence of unknown species described outside of their original distribution is not exceptional among bryozoans because several other species were described directly as nonindigenous (e.g., d'Hondt and Occhipinti-Ambrogi 1985; Souto et al. 2018; Miranda et al. 2018). Thus, we consider it as to be cryptogenic. Revision of this entire species complex will no doubt yield more new species and perhaps also help clarify the origin of $B$. serrata sp. nov.

Acknowledgments Open access funding provided by Austrian Science Fund (FWF). Thanks are due to the teachers and students of the course "Técnicas de muestreo y reconocimiento de organismos y comunidades bentónicas" from the "Máster interuniversitario en biología marina" during which the specimens from the Ria de Ferrol were collected; to María Corcuera, Daniel Arceniaga Alegría, Gorka Ruíz-Laorden, and the members of the diving club ASUT from Armintza for their assistance during diving at Point Etxandarri. Thanks also to Javier Sánchez Almazán, Francisco Yagüe Sánchez, Mary Spencer-Jones, and Paul Taylor for their help during the revision of the specimens stored in the MNCN and NHMUK. Thanks to Jean-Georges Harmelin, who sent samples from France.

We are grateful for the comments given by Jean-Georges Harmelin and three anonymous reviewers and editors who helped to improve the originally submitted manuscript considerably.
Funding This research was conducted thanks to the funds granted by the Austrian Science Fund (FWF, project number AP28954-B29). The work of Karine Nascimento and Leandro M. Vieira was supported by Conselho Nacional de Desenvolvimento Científico e Tecnológico (CNPq, project numbers 142058/2015-7 and 422563/2016-1) and by Coordenação de Aperfeiçoamento de Pessoal de Nível Superior (CAPES, project number 88881.135517/2016-01). Part of the revision of the samples was supported by the project "Fauna Ibérica: Briozoos II (Familia CribrilinidaeFamilia Watersiporidae)" (CGL2010-22267-C07-02), co-financed by the Ministerio de Economía y Competitividad (Spanish government) and FEDER.

\section{Compliance with ethical standards}

Conflict of interest The authors declare that they have no conflict of interest.

Ethical approval All applicable international, national, and/or institutional guidelines for the care and use of animals were followed.

Sampling and field studies All necessary permits for sampling and observational field studies have been obtained by the authors from the competent authorities and are mentioned in the acknowledgements, if applicable.

Open Access This article is distributed under the terms of the Creative Commons Attribution 4.0 International License (http:// creativecommons.org/licenses/by/4.0/), which permits unrestricted use, distribution, and reproduction in any medium, provided you give appropriate credit to the original author(s) and the source, provide a link to the Creative Commons license, and indicate if changes were made.

\section{References}

Allman GJ (1856) A monograph of the fresh-water polyzoa: including all the known species, both British and foreign. The Ray Society, London

Ayari-Kliti R, Afli A, Aissa P (2012) Diversite taxonomique des bryozoaires cheilostomes au large du Golfe de Tunis. Bull Inst Natn Sci Tech Mer Salammbô 39:73-116

Bastida R, Roux A, Martínez DE (1992) Benthic communities of the Argentine continental shelf. Oceanol Acta 15:687-698

Berning B (2006) The cheilostome bryozoan fauna from the Late Miocene of Niebla (Guadalquivir Basin, SW Spain): environmental and biogeographic implications. Mitt Geol-Palaontol Inst Univ Hamburg 90:7-156

Berning B, Kukliński P (2008) North-east Atlantic and Mediterranean species of the genus Buffonellaria (Bryozoa, Cheilostomata): implications for biodiversity and biogeography. Zool J Linnean Soc 152: 537-566

Bock PE (1982) Bryozoans (Phylum Bryozoa). In: Shepherd SA, Thomas IM (eds) Marine invertebrates of Southern Australia part 1. South Australian Government, Adelaide, pp 319-394

Bradstock M, Gordon DP (1983) Coral-like bryozoan growths in Tasman Bay, and their protection to conserve fish stocks. New Zeal J Mar Freshw Res 17:159-163

Busk G (1852) An account of the Polyzoa, and sertularian zoophytes, collected in the voyage of the Rattlesnake, on the coasts of Australia and the Louisiade Archipelago, \&c. In: MacGillivray J (ed) Narrative of the voyage of H.M.S. Rattlesnake, commanded by the late Captain Owen Stanley, R.S., F.R.S. \&C. during the years 1846 
1850, including discoveries and surveys in New Guinea, the Louisiade Archipelago, etc., to which is added the account of Mr. E.B. Kennedy's expedition for the exploration of the Cape York Peninsula, Vol. 1. T.W. Boone, London, pp 343-402 (Appendix IV) Busk G (1879) Polyzoa. Philos Trans R Soc Lond 168:193-199

Busk G (1884) Report on the Polyzoa collected by H.M.S. Challenger during the years 1873-1876. Part 1. The Cheilostomata. Report on the scientific results of the voyage of the H.M.S. Challenger. Zoology 10:1-216

Calvet L (1907) Bryozoaires. Expéditions scientifiques du Travailleur et du Talisman pendant les années 1880, 1881, 1882, 1883, 8:355-495

Calvet L (1927) Nouvelle contribution à l'histoire de la faune des Bryozoaires de la Méditerranée Occidentale. Arch Zool Exp Gén 66:1-6

Canu F, Bassler RS (1927) Classification of the cheilostomatous Bryozoa. Proc US Nat Mus 69:1-42

Carlton JT (2009) Deep invasion ecology and the assembly of communities in historical time. In: Rilov G, Crooks JA (eds) Biological invasions in marine ecosystems. Springer-Verlag, Berlin Heidelberg, pp 13-56

César-Aldariz J, Fernández-Pulpeiro E, Reverter-Gil O (1997) Briozoos de la costa de Lugo (N.O. España). Nova Acta Cient Compostel Biol 7:207-220 http://hdl.handle.net/10347/6714

Cocito S, Novosel M, Pasarić Z, Key MM (2006) Growth of the bryozoan Pentapora fascialis (Cheilostomata, Ascophora) around submarine freshwater springs in the Adriatic Sea. Linzer Biol Beitr 38:15-24

Connell SD (2001) Urban structures as marine habitats: an experimental comparison of the composition and abundance of subtidal epibiota among pilings, pontoons and rocky reefs. Mar Environ Res 52:115125

Cumming RL, Tilbrook KJ (2014) Six species of Calyptotheca (Bryozoa, Cheilostomata, Lanceoporidae) from the Gulf of Carpentaria and northern Australia, with description of a new species. Zootaxa 3827:147-169. https://doi.org/10.11646/zootaxa.3827.2.2

Cupido R, Cocito S, Sgorbini S (2007) Epibiosis in Parmunicea clavata after mortality events in the Ligurian Sea. Biol Mar Mediterr 14: $178-179$

d'Hondt JL (1979) Briozoos del Levante español. Bol R Soc Esp Hist Nat Secc Biol 77:457-471

d'Hondt JL, Ben Ismail D (2008) Bryozoaires des cotes algériennes. Compléments aux Bryozoaires de Tunisie. Bull Soc Zool Fr 133: $55-71$

d'Hondt JL, Mascarell G (2004) Les bryozoaires marins et d'eau douce de Tunisie. Bull Soc Zool Fr 129:437-457

d'Hondt JL, Occhipinti-Ambrogi A (1985) Tricellaria inopinata n.sp., un nouveau Bryozoaire Cheilostome de la faune Méditerrannée. Pubbl Stn Zool Napoli (Mar Ecol) 6:35-46

De Blauwe H, Faasse MA (2001) Extension of the ranges of the bryozoans Tricellaria inopinata and Bugula simplex in the North-East Atlantic Ocean (Bryozoa: Cheilostomatida). Nederl Faun Meded 14: $103-112$

Delle Chiaje S (1822) Memorie sulla storia e notomia degli animali senza vertebre del regno di Napoli. Societé Tipográfica, Napoli

Fehlauer-Ale KH, Mackie JA, Lim-Fong GE, Ale E, Pie MR, Waeschenbach A (2014) Cryptic species in the cosmopolitan Bugula neritina complex (Bryozoa, Cheilostomata). Zool Scr 43: 193-205

Fernández-Pulpeiro E, César-Aldariz J, Reverter-Gil O (2002) Sobre la presencia de Tricellaria inopinata d'Hondt y Occhipinti Ambrogi, 1985 (Bryozoa, Cheilostomatida) en el litoral gallego (N.O. España). Nova Acta Cient Compostel Biol [2001] 11:207-213. http://hdl.handle.net/10347/6631

Florence WK, Hayward PJ, Gibbons MJ (2007) Taxonomy of shallowwater Bryozoa from the west coast of South Africa. Afr Nat Hist 3: $1-58$
Gautier YV (1962) Recherches écologiques sur les Bryozoaires chilostomes en Méditerranée occidentale. Rec Trav St Mar Endoume 38(24):1-434

Gerovasileiou V, Rosso A (2016) Marine Bryozoa of Greece: an annotated checklist. Biodivers Data J 4:e10672. https://doi.org/10.3897/ BDJ.4.e10672

Glasby TM, Connell SD, Holloway MG, Hewitt C (2007) Non indigenous biota on artificial structures: could habitat creation facilitate biological invasions? Mar Biol 115:887-895

Gordon DP (1970) Reproductive ecology of some northern New Zealand Bryozoa. Cah Biol Mar 11:307-323

Gordon DP (1984) The marine fauna of New Zealand: Bryozoa: Gymnolaemata from the Kermadec Ridge. New Zeal Oceanogr Inst Mem 91:1-198

Gordon DP (1986) The marine fauna of New Zealand: Bryozoa: Gymnolaemata (Ctenostomata and Cheilostomata Anasca) from the western south Island continental shelf and slope. New Zeal Oceanogr Inst Mem 95:1-121

Gordon DP (2007) Bryozoa of New Caledonia. In: Payri CE, Forges BR (eds) Compendium of marine species of New Caledonia, Documents scientifiques et techniques II 7. Volume special, Deuxième édition. IRD, Noumea, pp 159-170

Gordon DP, Taylor PD, Bigey FP (2009) Phylum Bryozoa. In: Gordon DP (ed) New Zealand Inventory of Biodiversity. Volume I. Animalia. Radiata, Lophotrochozoa, Deuterostomia. Canterbury University Press, Christchurch (New Zealand), pp 271-297

Gray JE (1848) List of the specimens of British animals in the collections of the British Museum. Part 1. Centrionae or radiated animals. Trustees of the British Museum, London. 91-151

Hamilton A (1898) A list of Recent and fossil Bryozoa collected in various parts of New Zealand. Trans Proc New Zeal 30:192-199

Harmelin J-G (1969) Bryozoaires récoltés au cours de la campagne du Jean Charcot en Mediterranée occidentale (août-septembre 1967). 1. Dragages. Bull Mus Natl Hist Nat 40:1179-1208

Harmelin JG (2017) Bryozoan facies in the coralligenous community: two assemblages with contrasting features at Port-Cros Archipelago (Port-Cros National Park, France, Mediterranean). Sci Rep Port-Cros Natl Park 31:105-123

Harmelin JG, Vieira LM, Ostrovsky AN, Cáceres-Chamizo JP, Sanner J (2012) Scorpiodinipora costulata (Canu \& Bassler, 1929) (Bryozoa, Cheilostomata), a taxonomic and biogeographic dilemma: complex of cryptic species or human-mediated cosmopolitan colonizer? Zoosystema 34:123-138. https://doi.org/10.5252/z2012n1a5

Harmelin JG, Bitar G, Zibrowius H (2016) High xenodiversity versus low native diversity in the south-eastern Mediterranean: bryozoans from the coastal zone of Lebanon. Mediterr Mar Sci 17:417-439. https:// doi.org/10.12681/mms.1429

Harmer SF (1926) The polyzoa of the Siboga Expedition, 2. Cheilostomata Anasca. Siboga Exped Rep 28b:183-501

Harmer SF (1957) The polyzoa of the Siboga Expedition, part 4. Cheilostomata Ascophora II. Siboga Exped Rep 28d:641-1147

Hastings AB (1943) Polyzoa (Bryozoa) I. Scrupocellariidae, Epistomiidae, Farciminariidae, Bicellariellidae, Aeteidae, Scrupariidae. Discov Rep 22:301-351

Hayward PJ (1974) Studies on the cheilostome bryozoan fauna of the Aegean island of Chios. J Nat Hist 8:369-402. https://doi.org/10. 1080/00222937400770321

Hayward PJ (1980) Cheilostomata (Bryozoa) from the South Atlantic. J Nat Hist 14:701-722. https://doi.org/10.1080/00222938000770591

Hayward PJ (1995) Antarctic cheilostomatous Bryozoa. Oxford University Press, Oxford, New York, Tokyo

Hayward PJ, Cook PL (1983) The South African Museum's Meiring Naude Cruises. Part 13, Bryozoa II. Ann S Afr Mus 91:1-161

Hayward PJ, McKinney FK (2002) Northern Adriatic Bryozoa from the vicinity of Rovinj, Croatia. Bull Am Mus Nat Hist 270:1-139 
Heller C (1867) Die Bryozoën des adriatischen Meeres. Verh Zool Bot Ges Wien 17:77-136

Hincks T (1885) Contributions towards a general history of the marine Polyzoa. Part XV. Cheilostomata - miscellaneous. Ann mag Nat Hist. Ser 5(15):254-257

Hincks T (1886) The Polyzoa of the Adriatic: a supplement to Prof. Heller's "Die Bryozoen des Adriatischen Meeres". Ann Mag Nat Hist 17:254-271

Hutton FW (1873) Polyzoa. In: Catalogue of themarine Mollusca of New Zealand, with diagnoses of the species. Government Printer, Wellington, pp 87-104

Hutton FW (1891) Revised list of the marine Bryozoa of New Zealand. Trans Proc New Zeal 23:102-107

Jackson JBC (1986) Models of dispersal of clonal benthic invertebrates: consequences for species' distributions and genetic structure of local populations. Bull Mar Sci 39:588-606

Johnston G (1840) Miscellanea Zoologica. Description of a new genus of British zoophyte. Ann Mag Nat Hist Ser 1(5):272-274

Jullien J (1888) Bryozoaires. Mission Scientifique du Cap Horn 18821883 6:1-92

Kluge H (1914) Die Bryozoen der Deutschen Süd-Polar Expedition 1901-1903: 1 Die Familien Aeteidae, Cellularidae, Bicellaridae, Farciminaridae, Flustridae, Membraniporidae and Cribrilinidae. Deutsche Südpolar-Expedition 1901-1903 15:599-678

Lamouroux JVF (1816) Histoire des polypiers Coralligènes Flexibles, vulgairement nommés Zoophytes. F.Poisson, Caen

Liuzzi MG, López-Gappa J (2011) Algae as hosts for epifaunal bryozoans: role of functional groups and taxonomic relatedness. J Sea Res 65:28-32

Livingstone AA (1927) Studies on Australian Bryozoa. No5. A check list of the marine Bryozoa of Queensland. Rec Aust Mus 16:50-69

López-Gappa J (1989) Overgrowth competition in an assemblage of encrusting bryozoans settled on artifical substrata. Mar Ecol Prog Ser 51:121-130

López-Gappa J, Liuzzi MG (2018) Recent discovery of nonindigenous bryozoans in the fouling assemblage of Quequén Harbour (Argentina, Southwest Atlantic). Mar Biodivers 48:1159-1167. https://doi.org/10.1007/s12526-016-0561-7

MacGillivray PH (1887) A catalogue of the marine Polyzoa of Victoria. Trans Proc R Soc Vict 23:187-224

MacKinney FK, Jackson JBC (1989) Bryozoan evolution. Studies in Paleobiology. Urwin Hyman, Boston, pp 1-238

Marchini A, Galil BS, Occhipinti-Ambrogi A (2015) Recommendations on standardizing lists of marine alien species: lessons from the Mediterranean Sea. Mar Pollut Bull 101:267-273. https://doi.org/ 10.1016/j.marpolbul.2015.09.054

Miranda AA, Almeida ACS, Vieira LM (2018) Non-native marine bryozoans (Bryozoa: Gymnolaemata) in Brazilian waters: assessment, dispersal and impacts. Mar Pollut Bull 130:184-191. https://doi. org/10.1016/j.marpolbul.2018.03.023

Moran PJ, Grant TR (1989) The effects of industrial pollution on the development and succession of marine fouling communities. II. Multivariate analysis of Succession. Mar Ecol 10:247-261

Moran PJ, Grant TR (1991) Transference of marine fouling communities between polluted and unpolluted sites: impact on structure. Environ Pollut 72:89-102

Moran PJ, Grant TR (1993) Larval settlement of marine fouling organisms in polluted waer from Port Kembla Harbour, Australia. Mar Pollut Bull 26:512-514

Moyano HI (1999) Magellan Bryozoa: a review of the diversity and of the Subantarctic and Antarctic zoogeogeographical links. Sci Mar 63: 219-226

Moyano HI (2005) Scotia Arc bryozoans from the LAMPOS expedition: a narrow bridge between two different faunas. Sci Mar 69(Suppl 2): $103-112$
Moyano HI (2009) Ectoprocta-moss animals. In: Häusserman V, Fösterra G (eds) Marine benthic fauna of Chilean Patagania. Nature in Focus, Puerto Montt (Chile), pp 739-784

Neviani A (1896) Briozoi fossili della Farnesina e di Monte Mario presson Roma. Palaeontogr Ital 1(1895):77-140

Novosel M, Požar-Domac A (2001) Checklist of Bryozoa of the eastern Adriatic Sea. Natura Croatica 10:367-421

Novosel M, Pozar-Domac A, Pasaric M (2004) Diversity and distribution of the Bryozoa along underwater cliffs in the Adriatic Sea with special reference to thermal regime. Mar Ecol 25:155-170. https:// doi.org/10.1111/j.1439-0485.2004.00022.x

O’Donoghue CH, Day JH (1957) Come South African Bryozoa. T Roy Soc S Afr 35:71-95

O'Donoghue CH, de Watteville D (1944) Additional notes on Bryozoa from South Africa. Ann Natal Mus 10:407-432

Oken L (1815) Lehrbuch der naturgeschichte, III, Zoologie Vol. Abteilung 1, Fleischlose Thiere: 1-842

Ortmann A (1890) Die Japanische Bryozoenfauna. Bericht über die von Herrn Dr. L. Döderlein im Jahre 1880-81 gemachten Sammlungen. Arch Naturgesch 54:1-74

Osburn RC (1950) Bryozoa of the Pacific coast of America, part 1, Cheilostomata-Anasca. Allan Hancock Pac Exped 14:1-269

Osburn RC (1953) Bryozoa of the Pacific coast of America, part 3, Cyclostomata, Ctenostomata, Entoprocta and Addenda. Allan Hancock Pac Exped 14:613-841

Pallas PS (1766) Elenchus Zoophytorum sistens generum Adumbrationes generaliores et specierum cognitarum succinctas describtions cum selectis auctorum synonymis. Hagae Comitum

Piola RF, Johnston EL (2008) Pollution reduces native diversity and increases invader dominance in marine hard-substrate communities. Divers Distrib 14:329-342

Prenant M, Bobin G (1966) Bryozoaires, deuxieme partie. Chilostomes Anasca. Fédération Française des sociétés de sciences naturelles, Paris

Ramalhosa P, Souto J, Canning-Clode J (2017) Diversity of Bugulidae (Bryozoa, Cheilostomata) colonizing artificial substrates in the Madeira Archipelago (NE Atlantic Ocean). Helgol Mar Res 71(1). https://doi.org/10.1186/s10152-016-0465-8

Reverter-Gil O, Souto J, Fernández-Pulpeiro E (2011) Revision of the genus Crepis Jullien (Bryozoa: Cheilostomata) with description of a new genus and family and notes on Chlidoniidae. Zootaxa 2993:122

Reverter-Gil O, Souto J, Fernández-Pulpeiro E (2016) Bryozoa I. Ctenostomata. In: Ramos MA et al (eds) Fauna Ibérica, vol 43. Museo Nacional de Ciencias Naturales. CSIC. Madrid, pp 1-305

Rocha RM, Vieira LM, Migotto AE, Amaral ACZ, Ventura CRR, Pitombo FB, Santos KC, Lopes RM, Pinheiro U, Marques AC (2013) The need of more rigorous assessments of marine species introductions: a counter example from the Brazilian coast. Mar Pollut Bull 67:241-243. https://doi.org/10.1016/j.marpolbul.2010. 12.014

Rodríguez-Prieto C, Freshwater DW, Sánchez N (2007) Vegetative and reproductive morphology of Gloiocladia repens (C. Agardh) Sánchez et Rodríguez-Prieto comb. nov. (Rhodymeniales, Rhodophyta), with a taxonomic re-assessment of the genera Fauchea and Gloiocladia. Eur J Phycol 42:145-162

Rosso A, Di Martino E (2016) Bryozoan diversity in the Mediterranean Sea: an update. Mediterr Mar Sci 17:567-607. https://doi.org/10. $12681 / \mathrm{mms} .1474$

Rosso A, Chimenz Gusso C, Balduzzi A (2010) Bryozoa. Biol Mar Mediterr 17(suppl):586-615

Rowden AA, Warwick RM, Gordon DP (2004) Bryozoan biodiversity in New Zealand region and implications for marine conservation. Biodivers Conserv 13:2695-2721

Saguar J, Boronat J (1987) Briozoos de las Islas Columbretes. In: Islas Columbretes. Contribución al estudio de su medio natural. 
Generalitat Valenciana, Consellería d'Obres Publiques, Urbanisme i Transports, Valencia, pp 391-415

Silén L (1941) Cheilostomata Anasca (Bryozoa) collected by Prof. Dr. Sixten Bock's expedition to Japan and the Bonin Islands 1914. Ark Zool 33A:1-130

Silén L (1972) Fertilization in the Bryozoa. Ophelia 10:27-34

Soule JD (1959) Results of the Puritan-American Museum of Natural History expedition to western Mexico. 6. Anascan Cheilostomata (Bryozoa) of the Gulf of California. Am Mus Novit 1969:1-54

Souto J, Reverter-Gil O, Fernández-Pulpeiro E (2010a) Gymnolaemate bryozoans from the Algarve (southern Portugal): new species and biogeographical considerations. J Mar Biol Assoc UK 90:14171439. https://doi.org/10.1017/S0025315409991640

Souto J, Fernández-Pulpeiro E, Reverter-Gil O (2010b) The genus Amathia Lamouroux (Bryozoa: Ctenostomata) in Iberian waters. Cah Biol Mar 51:181-195

Souto J, Ramalhosa P, Canning-Clode J (2018) Three non-indigenous species from Madeira harbors, including a new species of Parasmittina (Bryozoa). Mar Biodivers 48:977-986. https://doi. org/10.1007/s12526-016-0592-0

Templado J, Calvo M, García Carrascosa AM, Boisset F, Jiménez J (2002) Flora y Fauna de la Reserva Marina de las Islas Columbretes. Ministerio de Agricultura, Pesca y Alimentación, Madrid

Thiel M, Gutow L (2005) The ecology of rafting in the marine environment. II. The rafting organisms and community. Oceanogr Mar Biol 43:279-418

Vail LL, Wass RE (1981) Experimental studies on the settlement and growth of Bryozoa in the natural environment. Aust J Mar Freshw Res 32:639-656

Vieira LM, Spencer Jones ME, Winston JE (2013) Cradoscrupocellaria, a new bryozoan genus for Scrupocellaria bertholletii (Audouin) and related species (Cheilostomata, Candidae): taxonomy, biodiversity and distribution. Zootaxa 3707:1-63. https://doi.org/10.11646/ zootaxa.3707.1.1
Vieira LM, Spencer Jones ME, Taylor PD (2014) The identity of the invasive fouling bryozoan Watersipora subtorquata (d'Orbigny) and some other congeneric species. Zootaxa 3857:151-182. https://doi.org/10.11646/zootaxa.3857.2.1

Waters AW (1879) On the Bryozoa (Polyzoa) of the Bay of Naples. Ann Mag Nat Hist Ser 5(3):114-126

Waters AW (1897) Notes on Bryozoa from Rapallo and other Mediterranean localities. J Linn Soc London, Zool 26:1-21

Waters AW (1904) Bryozoa. Résultats du Voyage du S.V. 'Belgica', Zoologie. Expedition Antarctique Belge 4:1-114

Waters AW (1906) Bryozoa from Chatham Island and d'Urville Island, New Zealand, collected by Professor H. Schauinsland. Ann Mag Nat Hist Ser 7(17):12-23

Watts PC, Thorpe JP, Taylor PD (1998) Natural and anthropogenic dispersal mechanisms in the marine environment: a study using cheilostome Bryozoa. Philos Trans R Soc Lond Ser B Biol Sci 353:453-464

Winston JE (1986) An annotated check-list of coral-associated bryozoans. Am Mus Novit 2859:1-39

Yanagi N, Okada Y (1918) On a collection of Japanese Cheilostomatous Bryozoa. I Annot Zool Jpn 9:407-429

Zabala M (1986) Fauna dels Briozous dels Països Catalans. Arxius de la Secció de Ciències 84:1-833

Zabala M (1993) Els Briozous. In: Alcover JA, Ballesteros E, Fornos JJ (eds) Història Natural de l'Arxipèlag de Cabrera, Monografies de la Societat d'Història Natural de les Balears, 2. CSIC y Moll. Palma de Mallorca, pp 561-577

Zabala M, Maluquer P (1988) Illustrated keys for the classification of Mediterranean Bryozoa. Treballs del Museu de Zoologia de Barcelona 4:1-294

Zenetos A, Cinar ME, Crocetta F, Golani D, Rosso A, Servello G, Shenkar N, Turon X, Verlaque M (2017) Uncertainties and validation of alien species catalogues: the Mediterranean as an example. Estuar Coast Shelf Sci 191:171-187. https://doi.org/10.1016/j.ecss. 2017.03.031 